\title{
The quantitative real-time PCR applications in the monitoring of marine harmful algal bloom (HAB) species
}

\author{
Penna Antonella • Galluzzi Luca
}

Received: 2 August 2012 / Accepted: 29 November 2012 /Published online: 18 December 2012

(C) The Author(s) 2012. This article is published with open access at Springerlink.com

\begin{abstract}
In the last decade, various molecular methods (e.g., fluorescent hybridization assay, sandwich hybridization assay, automatized biosensor detection, real-time PCR assay) have been developed and implemented for accurate and specific identification and estimation of marine toxic microalgal species. This review focuses on the recent quantitative real-time PCR (qrt-PCR) technology developed for the control and monitoring of the most important taxonomic phytoplankton groups producing biotoxins with relevant negative impact on human health, the marine environment, and related economic activities. The high specificity and sensitivity of the qrt-PCR methods determined by the adequate choice of the genomic target gene, nucleic acid purification protocol, quantification through the standard curve, and type of chemical detection method make them highly efficient and therefore applicable to harmful algal bloom phenomena. Recent development of qrt-PCR-based assays using the target gene of toxins, such as saxitoxin compounds, has allowed more precise quantification of toxigenic species (i.e., Alexandrium catenella) abundance. These studies focus only on toxin-producing species in the marine environment. Therefore, qrt-PCR technology seems to offer the advantages of understanding the ecology of harmful algal bloom species and facilitating the management of their outbreaks.
\end{abstract}

Responsible editor: Philippe Garrigues

P. Antonella $(\bowtie) \cdot$ G. Luca

Department of Biomolecular Sciences,

University of Urbino, Viale Trieste 296,

Pesaro, Italy

e-mail: antonella.penna@uniurb.it
Keywords Copy number $\cdot$ Fluorescent probes $\cdot$ HAB species $\cdot$ Primers $\cdot$ qrt-PCR $\cdot$ Ribosomal genes $\cdot$ SYBR Green · TaqMan

\section{Introduction}

Nowadays, it has become essential to have new and rapid methods to accurately process and specifically detect harmful algal bloom (HAB) species in monitoring programs for marine coastal ecosystems. These methods offer the advantages of understanding the presence of HAB species and their distribution and dispersion mechanisms, and facilitate the prevention or mitigation of the harmful effects of $\mathrm{HAB}$ species on human health, the marine ecosystem, and related economic activities. In the monitoring programs of HAB occurrences, the detection and quantification of target harmful species are generally carried out using only optical microscopy, making it nearly impossible to assess the species-specific identification of cells in relation to cryptic species (i.e., Pseudo-nitzschia spp.) or those with extremely difficult morphotype identification (i.e., Alexandrium spp., Chattonella spp., Ostreopsis spp.). In some cases, preservation procedures using Lugol or formalin fixatives are crucial for cell integrity and the critical conservation of fixed samples due to the prolonged time needed for analysis. In fact, in common monitoring strategies, the number of collected field samples to be analyzed, together with using microscopy for taxonomical species identification, dramatically reduces the early detection of the initiation and dispersion of harmful bloom phases. Moreover, optical microscopy retains a limit of quantitative sensitivity for harmful species detection and abundance estimation in natural samples. Sometimes, the toxicity of contaminated mussels in 
aquaculture farms is related to a very early outbreak of harmful species and/or their concomitant presence at a very low concentration in the seawater column (i.e., Dinophysis spp.). It was also demonstrated that the monitoring of sediments in the sea bottom for the presence of harmful species is important to determine the dynamics of vegetative cell dispersion in the water column to the deep bottom (Garcés et al. 2004; Erdner et al. 2010; Penna et al. 2010).

Because of the limitations of classical methods in monitoring programs, advances in molecular methodologies for the determination and quantification of microalgal complex diversity in marine natural environments have been carried out (Godhe et al. 2007). These advances imply the development and application of several molecular assays based on different molecular technologies. Hybridization assays, such as fluorescence in situ hybridization or sandwich hybridization assay (SHA), involve the use of species-specific rRNAtargeted probes that can hybridize selectively to nucleic acids when entire cells are preserved with fixatives or lysed, respectively (Scholin et al. 1999; Töbe et al. 2006; Greenfield et al. 2008; Töbe et al. 2010). In particular, several applications of SHA have been demonstrated (Ayers et al. 2005; Marin and Scholin 2010; Ryan et al. 2011; Diercks et al. 2011).

Quantitative real-time PCR (qrt-PCR) is an extremely sensitive molecular method that has been developed and applied in recent years to identify and estimate toxic phytoplankton species in marine natural samples (Chang et al. 2010; Galluzzi and Penna 2010; Delaney et al. 2011; Perini et al. 2011). The qrt-PCR application has revolutionized the study of microalgal population dynamics in marine ecosystems, since it permits the concomitant identification and enumeration of target phytoplankton species in field samples (Galluzzi et al. 2004). The PCR or qrt-PCR can be applied to seawater, sediments, and seafood animals having incorporated into their body the toxic species by filtration (Galluzzi et al. 2005; Murray et al. 2009). The method is based on the amplification of the specific genomic DNA sequences that are usually represented by ribosomal gene sequences. The first applications of qrt-PCR in the monitoring of toxic phytoplankton date back to early 2000 (Bowers et al. 2000; Popels et al. 2003). The quantitative application in seawater was demonstrated by Galluzzi et al. (2004) with the toxic dinoflagellate Alexandrium minutum. A qrt-PCR assay was developed for the rapid detection and quantification of A. minutum in water samples of the Mediterranean area of Spain and was based on a standard curve constructed with a plasmid containing the cloned ITS-5.8S rDNA sequence and cultured cells. First, it was possible to estimate the absolute number of $5.8 \mathrm{~S}$ rDNA copies per cell. Consequently, after quantification of 5.8S rDNA copies in seawater samples containing A. minutum cells, it was also possible to estimate the number of cells. Moreover, a comparative analysis of $A$. minutum abundance determined both by molecular qrt-PCR and standard microscopy methods was carried out. The two methods gave comparable results, confirming that qrt-PCR assay could be a valid and rapid alternative procedure for the detection and quantification of target $\mathrm{HAB}$ species during coastal water monitoring. Furthermore, a number of applications of qrt-PCR assays have been developed and applied for the quantitative detection of HAB phytoplanktonic species. The purposes of this review are to furnish a general overview of existing qrt-PCR technologies and assays available for HAB species monitoring in marine water and to provide background information to scientists approaching this technology and/or scientists who want to apply existing assays or develop new ones. A summary of these qrt-PCR applications is given in Table 1.

\section{Quantitative real-time PCR technologies}

Quantitative real-time PCR is widely used in clinical and environmental diagnostics to obtain reliable and accurate qualitative, as well as quantitative, information on microbial species. Quantification is performed during the exponential phase of the PCR, where amplification efficiency is maximum, avoiding problems that are associated with so-called "end-point" analysis. In fact, in real-time PCR, amplicon formation is monitored after each cycle by measuring a fluorescence signal. The increase in fluorescence observed during the reaction will be proportional to the starting quantity of the target molecule. Since there is a correlation between the cycle number at which the amplicon is initially detected (threshold cycle, $C_{\mathrm{t}}$ ) and the starting amount of target molecules, it is possible to calculate the amount of target sequence in an unknown sample by using a standard reference curve generated using the target sequence cloned into a plasmid or using the DNA extracted from a known number of cultured cells. Since real-time PCR is a closedtube system in which post-PCR analysis is not required, the potential for carryover contamination is eliminated, and the time of analysis is shortened.

Fluorescence can be generated by using intercalating fluorescent dyes (e.g., SYBR Green, EVA Green) or fluorescent probes such as TaqMan ${ }^{\circledR}$ and molecular beacons. The use of intercalating dyes is the cheaper and simplest approach and consists of adding the fluorescent dye directly to the PCR mixture. These dyes bind to double-stranded DNA, undergo a conformational change, and emit fluorescence at a greater intensity. As amplicon numbers accumulate after each PCR cycle, there is a corresponding increase in fluorescence. The assays based on intercalating dyes are characterized by high sensitivity, but it is essential that primers are highly specific to their target sequence to avoid generation of nonspecific products that would lead to 


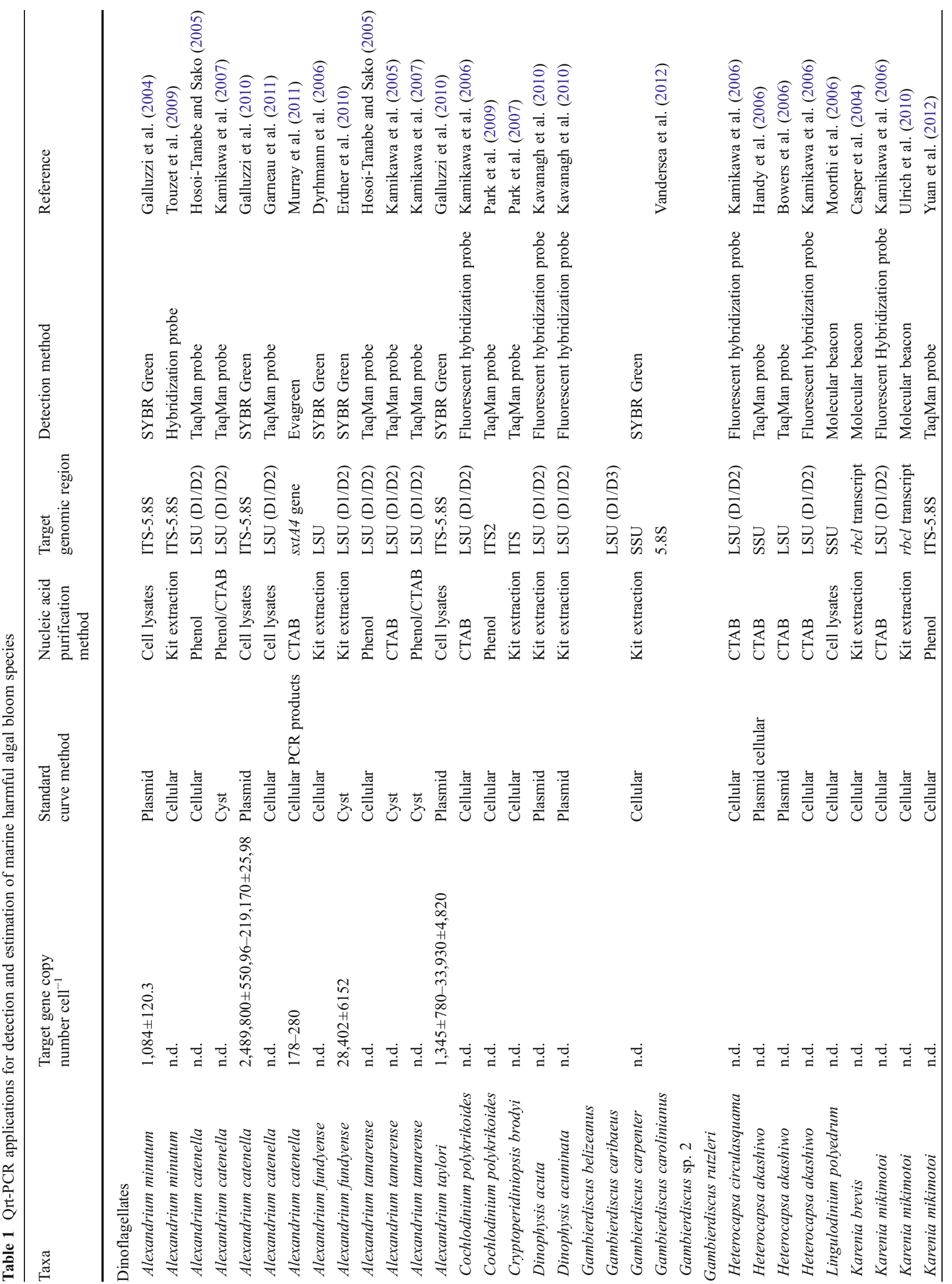




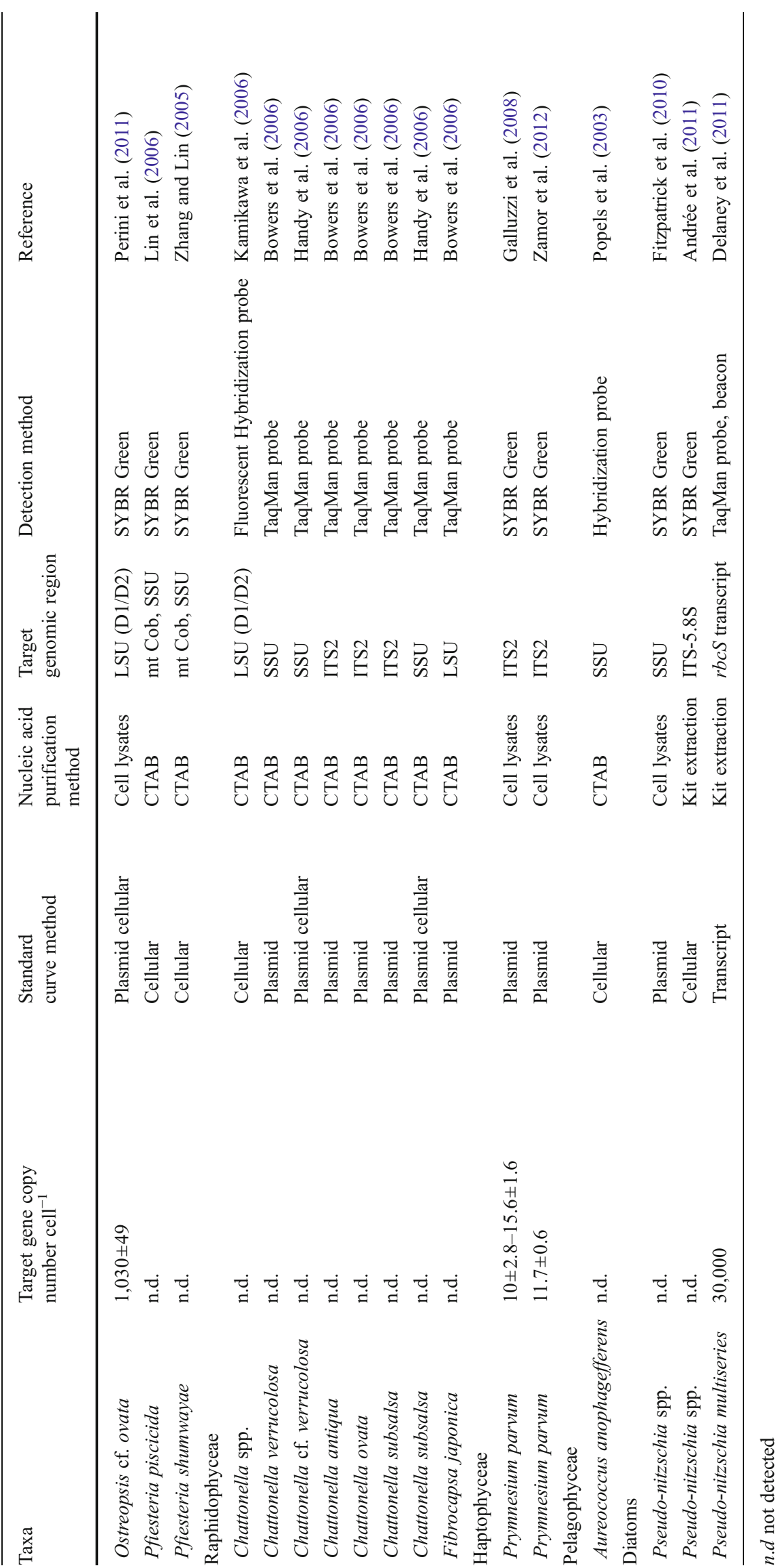


overestimated or false-positive results. Primer pairs exhibiting self-complementarity should be avoided to prevent primer dimer formation. A post-PCR melting curve analysis should be performed to confirm the presence of a single specific amplicon in much the same way as agarose gel electrophoresis is used to analyze an end-point PCR. Alternatively, for genotyping purposes, high-resolution melt (HRM) analysis can be used to differentiate amplicons based on sequence or length variations (Reed et al. 2007). HRM analysis is enabled by novel saturation dyes such as LC Green (Tindall et al. 2009) and real-time thermal cyclers incorporating high-resolution melting, with thermal resolutions below $0.1{ }^{\circ} \mathrm{C}$, such as Light Cycler 480 (Roche) and Rotor-Gene Q (Qiagen).

The TaqMan ${ }^{\circledR}$ probes are designed to be complementary to a sequence located between the two primers used for PCR amplification. These probes are modified with a fluorescent reporter and a quencher conjugated at the $5^{\prime}$ and 3' ends (Livak et al. 1995). Due to the close proximity of these two dye molecules, the fluorescence of the reporter is quenched through fluorescence resonance energy transfer. During the extension step of PCR, the DNA polymerase degrades the TaqMan ${ }^{\circledR}$ probe, resulting in the separation of the reporter from the quencher and an increase in fluorescence emission. Due to the additional specificity provided by the presence of the TaqMan probe, this approach is less subject to false positives than the intercalating dye method, but can be more expensive. Different probes can be labeled with different fluorophores, allowing multiplexing protocols, where different targets can be coamplified and quantified within a single reaction tube (Fyfe et al. 2007). Advancement in TaqMan probe technology is represented by the introduction of the minor groove binder (MGB) probe (Kutyavin et al. 2000). The MGB molecule is attached to the $3^{\prime}$ end of the probe and essentially folds back onto the probe, increasing stability and allowing the design of shorter probes while at the same time maintaining the required hybridization annealing temperature.

Molecular beacons are oligonucleotide probes that can adopt a stem-loop structure by the annealing of complementary sequences at its $5^{\prime}$ and $3^{\prime}$ ends (Goel et al. 2005). The sequence in the loop is complementary to the target region. Similar to the TaqMan ${ }^{\circledR}$ probe, a reporter fluorescent dye and a quencher are covalently linked at each end of the molecule. In the "closed" conformation, the reporter fluorophore and the quencher are in proximity, and the probe is switched off. When the probe loop anneals to its target sequence, forming a probe-target hybrid (with greater stability than the stem structure), the fluorophore and the quencher are separated from each other, and a fluorescent signal can be observed. This signal is proportional to the amount of DNA amplified.

\section{Target sequences, nucleic acid extraction, and curve standard for quantification}

PCR-based assays for the detection of various toxic dinoflagellates in seawater have generally employed ribosomal DNA regions as the target. This is because rRNA genes are phylogenetically informative and tandemly repeated in high copy numbers (enhancing the assay sensitivity). Different regions of the rDNA cluster include the small subunit (SSU), the large subunit (LSU), the 5.8S region, two internal transcribed spacers (ITS1, ITS2), and the nontranscribed spacer. The choice of a particular region as the target is based mostly on the level of variability of each region within a particular species of interest and the requirements of assay specificity and sensitivity (Bena et al. 1998). The recent identification of genes involved in the production of the saxitoxin (STX) in marine eukaryotic phytoplankton has allowed the design of assays for detecting and quantifying the potential for STX production in marine environmental samples. Murray et al. (2011) developed a qrt-PCR assay to detect and quantify a domain of the gene $s x t A$, encoding a unique enzyme (sxtA4) putatively involved in the STX pathway in marine dinoflagellates. The sxtA4 gene copy number has been shown to be relatively constant among Alexandrium catenella strains, allowing the detection and quantification of blooms of $A$. catenella that lead to STX uptake in oysters.

Several DNA extraction methods give highly purified nucleic acids from marine algae, but DNA yield and extraction reproducibility can be poor. In fact, low amounts of DNA can be recovered from an established cell number by kit purification, and this can interfere with the reproducibility of DNA amplification for the estimation of cell number. Because of this, for quantification purposes, qrt-PCR reactions can also be performed using crude lysates from cultured and natural samples (Galluzzi et al. 2004; Garneau et al. 2011; Perini et al. 2011). To elude any inhibitory effect of PCR amplification reaction, cell lysates containing DNA can be diluted until the potential inhibitory effects of contaminants are eliminated. The dilution approach is possible where rRNA genes are used as the target, because in most eukaryotes, the rRNA gene family is repeated in tandem in high copy number.

Many real-time PCR protocols have been optimized for the quantitative approach using different types of standard curves. In principle, these can be generated using a plasmid containing the cloned target sequence (generally rRNA genes) (Créach et al. 2006). When a cloned sequence is used as a reference standard, it is essential to know the amount of target gene per cell in order to allow the determination of the cell number in the field sample. This can be particularly important for rRNA genes, due to their high and variable copy number. To this end, cellular standard curves 
can be used together with plasmid-based curves. The cellular standard curves can be generated from crude lysates of target cell serial dilutions spiked into natural and filtered seawater or medium (Fitzpatrick et al. 2010; Garneau et al. 2011), or from serial dilutions of DNA extracted from clonal cultures (Godhe et al. 2008; Andrée et al. 2011). However, it has to be considered that the determination of copy numbers of the target DNA sequence only provides a rough correlation to cell abundance because it does not take into account the potential intra-species variability in gene copy number or the effect of the growth phase (Galluzzi et al. 2010). In fact, high rRNA gene content variability has been demonstrated in Alexandrium species (i.e., A. catenella and Alexandrium taylori). The variability of gene content was among strains and through the growth phases. This can compromise the accuracy of qrt-PCR counts of target cells in field samples, as well as lead to a correspondence with microscopy determinations. In Mediterranean field samples, the comparison between the number of cells counted by microscope and calculated through qrt-PCR has shown some significant differences $(p<0.01)$. More presumably, A. catenella and A. taylori rRNA gene variability can influence the correct quantification of cell abundance in the environment. It could be inferred that the rRNA gene content could be different between isolate-cultured cells and cells in natural environment, and this can be partially explained by the presence of the rRNA pseudo-gene in the Alexandrium tamarense species complex (Yeung et al. 1996). Therefore, the molecular quantification model, as discussed, fails in A. catenella due to pseudo-gene instability depending on isolate, growth phase, culture conditions, and environmental variables. The rRNA gene content variability has also been reported for Alexandrium spp. cysts; this variability led to some differences among qrt-PCR and microscope-based counts; however, the values resulted significantly correlated (Erdner et al. 2010).

Recently, Perini et al. (2011) developed a qrt-PCR method based on SYBR Green I that combines the use of a plasmid standard curve with a "gold standard" created with pooled crude extracts from environmental samples collected during a bloom of toxic benthic dinoflagellate Ostreopsis cf. ovata in the Mediterranean Sea. Because of similar PCR efficiencies of the two curves, the rDNA copy number per cell was obtained in cultured and environmental samples. The analytical sensitivity of the PCR assay was set at two rRNA gene copies and $8.0 \times 10^{-4}$ cells per reaction for the plasmid and gold standards, respectively (Fig. 1).

\section{Quantitative real-time PCR applications}

Qrt-PCR has been used in the last years to detect and quantify various toxic phytoplankton groups in environmental marine samples. These include mainly dinoflagellates and Raphidophyceae, but also Haptophyceae, Pelagophyceae, diatoms and Cyanophyceae. Representative genera among these groups are Alexandrium (Galluzzi et al. 2004; Hosoi-Tanabe and Sako 2005; Dhyrman et al. 2006; Erdner et al. 2010; Garneau et al. 2011), Karenia (Casper et al. 2004; Kamikawa et al. 2006; Yuan et al. 2012), Cochlodinium, Heterocapsa, Chattonella, Heterosigma (Kamikawa et al. 2006; Coyne et al. 2005; Howard et al. 2012), Prymnesium (Galluzzi et al. 2008; Zamor et al. 2012), Pseudo-nitzschia (Fitzpatrick et al. 2010; Andrée et al. 2011; Delanaey et al. 2011), Dinophysis (Kavanagh et al. 2010), Gambierdiscus (Vandersea et al. 2012), and Ostreopsis (Perini et al. 2011).

\section{Dinoflagellates}

Qrt-PCR-based assays were mostly applied to the neurotoxic species within genus Alexandrium. The paralytic toxins detected in shellfish provide evidence that harmful events have occurred with increased frequency and severity along coastal areas worldwide during the last 20 years, even if the timing and location of the paralytic shellfish poisoning occurrences are highly variable (Glibert et al. 2005; Moore et al. 2009; Halleagraeff 2010). Recently, the detection and quantification of Alexandrium cells in natural water samples were coupled with the determination of STX compounds by analytical methods or STX genes by a molecular qrt-PCR assay. In fact, it is highly useful to obtain information on both Alexandrium abundance and STX content to fix the minimum threshold cell number for toxic contamination events. The species A. catenella can produce STX compounds with health risk at low densities $\left(1,000\right.$ cells L $\left.{ }^{-1}\right)$ (Jester et al. 2009).

In the study of Gaurneau et al. (2011), low cell numbers of $A$. catenella determined by qrt-PCR were compared with STX concentrations in surface seawater samples at King Harbor, California, USA. Species-specific primers for the A. catenella morphotype (A. tamarense species complex, group I) (Lilly et al. 2007) were designed based on LSU rDNA (D1/D2) together with a hybridization probe (i.e., molecular beacon) to increase the specificity of the method. A standard curve was obtained from serial dilutions of cultured cell lysates of A. catenella in filtered or natural seawater. The range of abundance used in the calibration curves was of four orders of magnitude (from $10^{1}$ to $10^{5}$ cells $\mathrm{L}^{-1}, r^{2}=0.99$ ). The $\mathrm{qPCR}$ assay was calibrated in this study in order to estimate $A$. catenella abundance in natural samples directly from the $C_{\mathrm{t}}$ values. The sensitivity of this qrt-PCR approach permitted the determination of cells at the lower detection limit of optical microscopy $\left(<12\right.$ cells $\left.\mathrm{L}^{-1}\right)$. Furthermore, the abundance of $A$. catenella in the harbor was not necessarily associated with detectable STX concentrations, opening the question of toxin transfer to a higher level of the trophic web. 


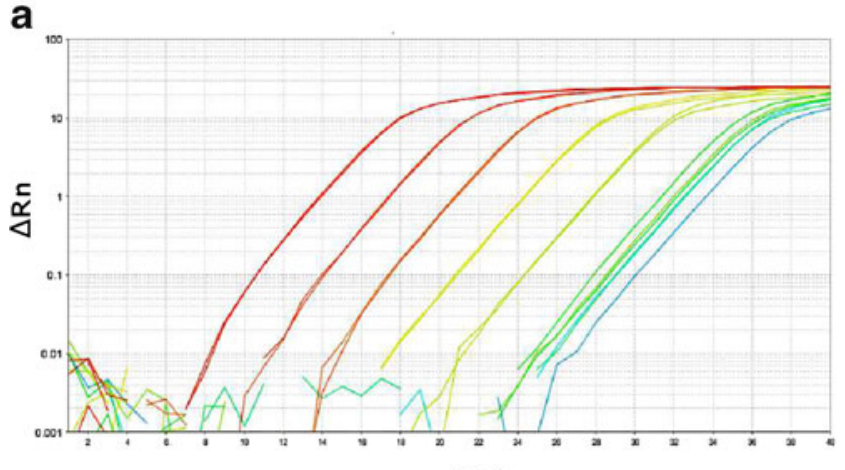

Cycle

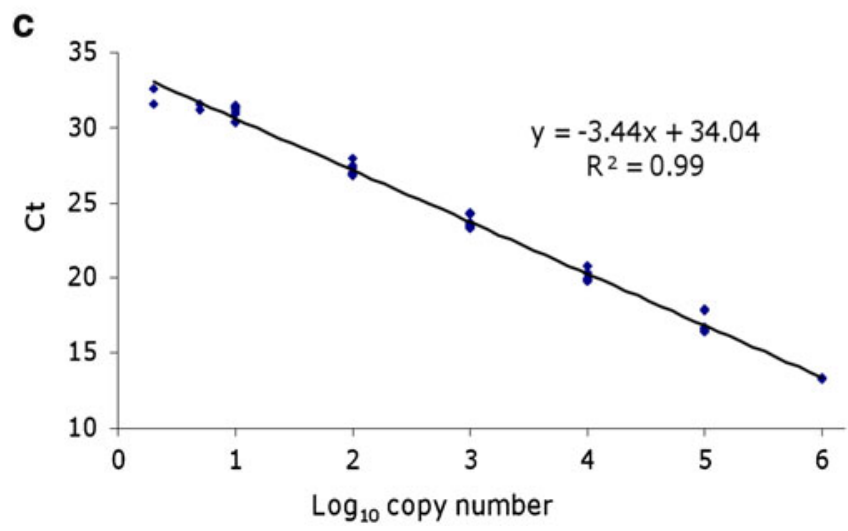

Fig. 1 Examples of amplification plots generated from dilutions of a target sequence (LSU rDNA from Ostreopsis cf. ovata) cloned into a plasmid (a) and from $O$. cf. ovata cell dilutions (b). The corresponding

An innovative qrt-PCR approach on toxigenic Alexandrium spp. quantification was done by Murray et al. (2011). A qrt-PCR method to detect and quantify the potential for STX production in the marine environment based on quantification of sxtA was developed. The $s x t A$ is a gene putatively involved in the biosynthesis of marine toxin (Stüken et al. 2011). Specific detection of the sxtA4 gene domain is associated with STX-producing cultured species (A. catenella, A. tamarense, Gymnodinium catenatum) and environmental samples containing known STX-producing species in Australian seawaters. A standard curve was constructed with both PCR-amplified products of sxtA4 gene and serial dilutions of amplified genomic DNA from cultured A. catenella cells. The standard curve was used to determine the PCR efficiency and copy number of the sxtA4 gene per cell. In three cultured strains of $A$. catenella, the copy number per cell of sxtA4 was in the range of 178 280 , and it was determined that these strains produced similar amounts of STX analogues. In the environmental samples, the correlation between sxtA4 copies per liter and cell abundance per liter was highly significant, as was the correlation with the content of STX compounds in filterfeeding animals such as oysters. These findings can be further correlated with toxin accumulation in filter bivalves

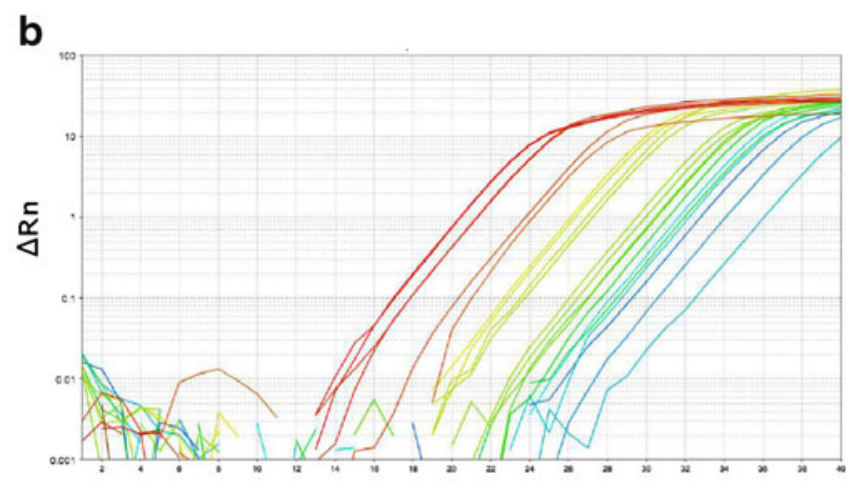

Cycle

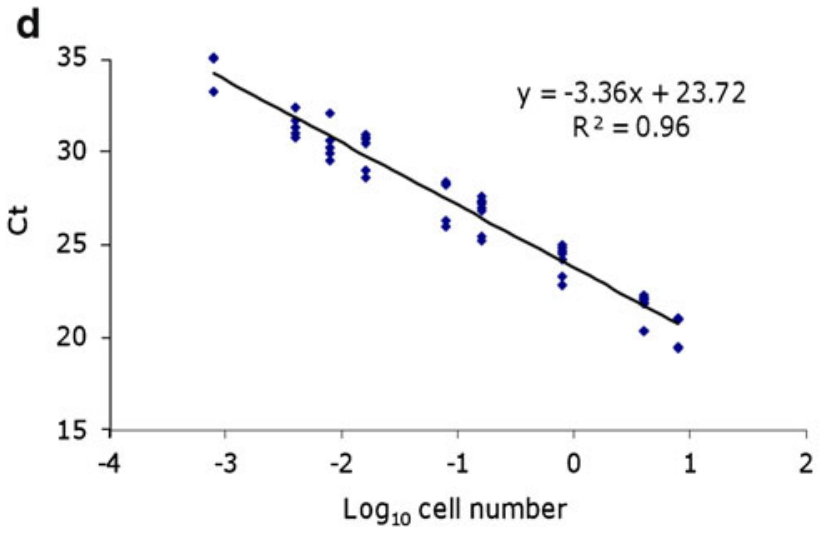

standard curves $(\mathbf{c}, \mathbf{d})$ were obtained by the correlation of $C_{\mathrm{t}}$ values and $\log _{10}$ input plasmid copies or environmental cell number, respectively. Adapted from Perini et al. (2011)

to test if STX gene quantification can be a tool for controlling and monitoring toxic species and their toxin accumulation.

Recently, real-time PCR detection of toxic Dinophysis species along the Irish coasts was also developed (Kavanagh et al. 2010). The qrt-PCR method was performed to detect two co-existing toxic species, as Dinophysis acuta and $D$. acuminata. Due to the high similarity of nucleotide sequence alignment in the ribosomal regions, a set of genus-specific primers and two species-specific hybridization probes targeting the D1/D2 region in LSU gene were designed. The reporter probe was designed to have a few mismatches (4 bp) between $D$. acuta and D. acuminata. Genomic DNA was extracted from isolated D. acuta and $D$. acuminata cells from seawater samples. After the qrtPCR amplification, through probe melt analysis, it was possible to differentiate the two species: $D$. acuta and $D$. acuminata were characterized by melting peaks at 61 and $48{ }^{\circ} \mathrm{C}$, respectively. The sensitivity of this qrt-PCR assay was set up to ten copies of plasmid for both species; however, it was not possible to generate a standard curve based on known cell number due to bias in DNA extraction from low amounts of cells that were not possible to cultivate. Anyway, a good correlation between qrt-PCR and 
microscopy determinations of Dinophysis species was obtained with a higher level of sensitivity of the qrt-PCR assay.

\section{Diatoms}

Recently, a number of qrt-PCR assays to quantify toxic Pseudo-nitzschia species were developed. Outbreaks of domoic acid along US coasts have caused sickness and death of marine mammals and seabirds through food web contamination. In European waters, shellfish aquaculture contamination is a big concern causing the closure of sampling and commercialization of seafood products with enormous economic losses. Pseudo-nitzschia bloom intensity has increased over the past 20 years (Trainer et al. 2012). Moreover, Pseudo-nitzschia species can include very similar morphotypes, and some of them can be toxic (i.e., Pseudonitzschia pseudodelicatissma). The qrt-PCR assay has permitted the detection and quantification of toxigenic specimens at low concentration.

In Fitzpatrick et al. (2010), a qrt-PCR approach for genus Pseudo-nitzschia quantification on the US East Coast was developed. A lysis protocol for cell rupture and the use of SYBR Green as the fluorescent dye were adopted. Genusspecific primers were designed based on $18 \mathrm{~S}$ rDNA sequences. In fact, no species-specific designs were possible, indicating the low level of $18 \mathrm{~S}$ variability among Pseudonitzschia spp. The quantification assay was done using a curve created from serial dilutions of Pseudo-nitzschia spp. cultures (Pseudo-nitzschia australis, Peudo-nitzsch pungens, $P$. delicatissima). However, the quantification of natural samples was carried out using the standard curve obtained from serial dilutions of cultured $P$. australis serial dilution cells since the bloom was highly dominated by $P$. australis, as recognized by SEM. The results of the qrt-PCR assay were validated using microscopy counts.

Another recent qrt-PCR approach for Pseudo-nitzschia spp. estimation was performed by Andrée et al. (2011) using SYBR Green as the intercalating dye. First, specific primers were designed based on the ITS-5.8S rDNA regions of a series of Pseudo-nitzschia species isolated at Alfacs Bay (Catalan Sea, Mediterranean Sea, Spain). The speciesspecific differentiation of PCR-amplified products was associated to the melting curve profiles for each Pseudo-nitzschia species examined. Genomic DNA was extracted from cultures and seawater samples for the qrt-PCR assay. Standard curves were constructed using serial dilutions of genomic DNA purified from different species (Pseudo-nitzschia calliantha, $P$. delicatissima, $P$. multistriata, and $P$. pungens). The qrt-PCR quantification of several Pseudonitzschia spp. in field samples during blooms in 20072008 was always correlated with optical microscopy counts, and the overall trend for both methods of Pseudo-nitzschia detection showed significant statistical correlations. Therefore, this evidence demonstrated the applicability and reliability of a quantification assay for the toxigenic Pseudonitzschia species that often co-occur mixed with nontoxic species in bloom events.

Since ecological and environmental studies often rely on an accurate estimation of the density of a particular phytoplankton class or the ratios between the different taxonomic classes, two real-time PCR assays targeting the SSU rDNA were designed using class-specific primers to assess the proportional biomass of diatoms and dinoflagellates in marine coastal water (Godhe et al. 2008). After the establishment of a significant correlation between the number of SSU rDNA copies and the biovolumes of diatoms and dinoflagellates, this approach was successfully applied to estimate the proportion of dinoflagellate versus diatom biovolume or biomass in field samples.

\section{Haptophyceae}

Among the toxic haptophytes, qrt-PCR assays have been developed for Prymnesium parvum, which has been associated with extensive fish mortality (Hallegraeff 1992). The early and sensitive detection of $P$. parvum is essential for improving bloom monitoring and management strategies. Monitoring with conventional microscopy-based methods is difficult because the cells are small, fragile, and morphologically similar to closely related species. In recent years, a quantitative real-time PCR approach based on the use of the intercalating dye SYBR Green has been established (Galluzzi et al. 2008), and a modified version of this method has been validated and used in a routine $P$. parvum monitoring program (Zamor et al. 2012). Moreover, qualitative and quantitative multiplex real-time PCR, based on the use of molecular beacons, has also been attempted (Manning and La Claire 2010).

\section{Cyanobacteria}

Cyanobacteria toxin poisonings occur in fresh and brackish waters throughout the world. The main genera responsible include Anabaena, Aphanizomenon, Cylindrospermopsis, Lyngbya, Microcystis, Nostoc, and Oscillatoria (Planktothrix). Cyanobacteria toxins include neurotoxins (i.e., anatoxin-a, anatoxin-a(s), and saxitoxins) and hepatotoxins (i.e., microcystins, nodularins, and cylindrospermopsins). Cyanobacteria blooms in marine waters are limited to a few taxa with Trichodesmium, Richelia, Nodularia, and Aphanizomenon being most commonly observed (Sellner 1997). In particular, in the Baltic Sea, Nodularia spumigena forms toxic mass occurrences, posing health risks to humans, causing animal poisonings, harming fisheries, and interfering with the recreational use of waters. 
Since the gene clusters responsible for the synthesis of the microcystins, nodularin, and cylindrospermopsin have been described (Moffitt and Neilan 2004; Rouhiainen et al. 2004; Mihali et al. 2008) and the genes putatively responsible for the biosynthesis of saxitoxin have also been identified (Kellmann et al. 2008), several qrt-PCR assays targeted to toxin-coding genes have been developed to detect and quantify toxin-producing cyanobacteria. Koskenniemi et al. (2007) developed a SYBR Green-based qrt-PCR method targeting the nodularin gene. Specific primers were designed on the nodularin synthetase gene subunit $\mathrm{F}(n d a F)$, and the application of SYBR Green in qrtPCR was adopted. The standard curve was determined based on cellular DNA dilutions from different $N$. spumigena strains, and the gene copy number was determined. The qrt-PCR method was applied to seawater samples, and the detection of as few as 30 gene copies per milliliter of water in the Baltic Sea was possible. Further, ndaF gene copy numbers and nodularin concentrations were positively correlated, showing constant production of nodularin by the microalga.

Many qrt-PCR methods have been developed to monitor and to study toxic cyanobacteria population dynamics in fresh water and have been recently extensively reviewed (Martins and Vasconcelos 2011).

\section{Advantages and drawbacks}

The main advantages of real-time PCR techniques for the monitoring of phytoplankton are represented by high sensitivity, specificity, potential high throughput, and applicability to preserved environmental samples. This is particularly important since sample preservation is often necessary and can cause the morphological distortion of some phytoplankton species, making it more difficult to distinguish them from closely related species using microscopy-based techniques.

However, several aspects should be taken into account for the quantification of target sequences amplified from nucleic acids isolated from environmental samples. The choice of method used for nucleic acid extraction will determine the nucleic acid yield, which is often variable and well below $100 \%$, and the eventual presence of PCR inhibitors, such as humic acids, which can decrease the reaction efficiency (Wilson 1997). Yield problems can be addressed by using raw proteinase K-treated cell lysates, but the presence of PCR inhibitors necessitates the dilution of these samples until the environmental template and the standard curve target gene have equivalent amplification efficiencies. Therefore, to maintain the high sensitivity of the assay, the target sequence should be tandemly repeated in high copy number (e.g., rRNA genes).
In principle, a real-time PCR assay can be used to detect/quantify any phytoplankton species with available and phylogenetically informative DNA sequence data. However, due to the possibility of variations in target gene (mostly rRNA genes) copy number among different strains (Galluzzi et al. 2010) and in order to verify primer or probe specificity with environmental samples, the method should be optimized with the local phytoplankton population in the geographical area to be investigated. Generally, only one species or strain at a time can be analyzed in a quantitative approach, unless a multiplex reaction is performed. Real-time PCR multiplexing and multiprobing have been evaluated by Handy et al. (2006) for simultaneous enumeration of three raphidophyte species (Chattonella cf. verruculosa, Chattonella subsalsa, and Heterosigma akashiwo). Environmental samples containing these raphidophytes have been shown to be successfully multiplexed or multiprobed with only minimal losses in sensitivity. This approach opens up the possibility of rapidly enumerating multiple organisms within the same sample, but also introduces added complexity in method development (e.g., ensuring the primers and probes do not interfere and that the PCR efficiencies are similar for all assays). Concerning the costs, real-time PCR instruments and consumables are now affordable also for small research groups and are quite common in molecular biology-equipped laboratories.

\section{Conclusions}

Due to high specificity and sensitivity, quantitative real-time PCR could represent an efficient molecular tool for the detection of phytoplankton cells at the pre-bloom levels. The early detection of HAB species is necessary to determine the potential environmental factors that influence a bloom, to evaluate potential sources of low-level cell inoculations (i.e., natural or anthropogenic transport mechanisms) in coastal seawaters, and to provide early warning to safeguard human health and aquaculture. However, extensive validation in the investigated area may be necessary due to the possible variability in terms of target gene copy number and nucleotide sequence in different phytoplankton populations within the same species.

Due to the introduction of next-generation sequencing technologies and metagenomic approaches, the knowledge of HAB species genomes is expected to increase in the coming years. This could allow the identification of new genome target sequences (and determine their variability in terms of copy number) suitable to design reliable primers and probes, thus improving qrt-PCR trustworthiness as a tool for monitoring $\mathrm{HAB}$ species in the marine environment. 
Acknowledgments Financial support to A. P. was given by the Italian PRIN 2009 Project from Ministero Italiano Università e Ricerca (MIUR).

Open Access This article is distributed under the terms of the Creative Commons Attribution License which permits any use, distribution, and reproduction in any medium, provided the original author(s) and the source are credited.

\section{References}

Andrée KB, Fernandez-Tejedor M, Elandaloussi LM, Quijano-Scheggia S, Sampedro N, Garcés E, Camp J, Diogene J (2011) Quantitative PCR coupled with melt curve analysis for detection of selected Pseudo-nitzschia spp. (Bacillariophyceae) from the northwestern Mediterranean Sea. Appl Environ Microbiol 77:1651-1659

Ayers K, Rhodes LL, Tyrrell J, Gladstone M, Scholin C (2005) International accreditation of sandwich hybridisation assay format DNA probes for micro-algae. New Zeal J Mar Fresh Res 39:1225-1231

Bena G, Jubier MF, Olivieri I, Lejeune B (1998) Ribosomal external and internal transcribed spacers: combined use in the phylogenetic analysis of Medicago (Leguminosae). J Mol Evol 46:299-306

Bowers HA, Tengs T, Glasgow HB, Burkhoelder JMJ, Rublee PA, Oldach DW (2000) Development of real-time PCR assay for rapid detection of Pfiesteria piscicida and related dinoflagellates. Appl Environ Microbiol 66:4641-4648

Bowers HA, Trice TM, Magnien RE, Goshorn DM, Michael B, Schaefer EF, Rublee PA, Oldach DW (2006) Detection of Pfiesteria spp. by PCR in surface sediments collected from Chesapeake Bay tributaries (Maryland). Harmful Algae 5:342-351

Casper ET, Paul JH, Smith MC, Gray M (2004) Detection and quantification of the red tide dinoflagellate Karenia brevis by real-time nucleic acid sequence-based amplification. Appl Environ Microbiol 70:4727-4732

Chang CW, Wu YC, Ming KW (2010) Evaluation of real-time PCR methods for quantification of Acanthamoeba in anthropogenic water and biofilms. J Appl Microbiol 109:799-807

Coyne K, Handy SH, Demir E, Whereat EB, Hutchins DA, Portune KJ, Doblin MA, Craig Cary S (2005) Improved quantitative realtime PCR assays for enumeration of harmful algal species in field samples using an exogenous DNA reference standard. Limnol Oceanogr Meth 3:381-391

Créach V, Ernst A, Sabbe K, Vanelslander B, Vyverman W, Stal LJ (2006) Using quantitative PCR to determine the distribution of a semicryptic benthic diatom, Navicula phyllepta (Bacillariophyceae). J Phycol 42:1142-1154

Delaney JA, Ulrich RM, Paul JH (2011) Detection of the toxic marine diatom Pseudo-nitzschia multiseries using the RuBisCO small subunit (rbcS) gene in two real-time RNA amplification formats. Harmful Algae 11:54-64

Diercks S, Metfies K, Jéckel S, Medlin LK (2011) The ALGADEC device: a semi-automated rRNA biosensor for the detection of toxic algae. Harmful Algae 10:395-401

Dyhrman ST, Erdner D, Du JL, Galac M, Anderson DM (2006) Molecular quantification of toxic Alexandrium fundyense in the Gulf of Maine using real-time PCR. Harmful Algae 5:242-250

Erdner DL, Percy L, Keafer B, Lewis J, Anderson DM (2010) A quantitative real-time PCR assay for the identification and enumeration of Alexandrium cysts in marine sediments. Deep Sea Res II 57:279-287

Fitzpatrick E, Caron D, Schnetzer A (2010) Development and environmental application of a genus-specific quantitative PCR approach for Pseudo-nitzschia species. Mar Biol 157:1161-1169
Fyfe JA, Lavender CJ, Johnson PD, Globan M, Sievers A, Azuolas J, Stinear TP (2007) Development and application of two multiplex real-time PCR assays for the detection of Mycobacterium ulcerans in clinical and environmental samples. Appl Environ Microbiol 73:4733-4740

Galluzzi L, Penna A, Bertozzini E, Vila M, Garces E, Magnani M (2004) Development of a real-time PCR assay for rapid detection and quantification of Alexandrium minutum (a dinoflagellate). Appl Environ Microbiol 70:1199-1206

Galluzzi L, Penna A, Bertozzini E, Vila M, Garcés E, Giacobbe MG, Prioli S, Magnani M (2005) Development of a qualitative PCR method for the Alexandrium (Dinophyceae) detection in contaminated mussels (Mytilus galloprovincialis). Harmful Algae 4:973-983

Galluzzi L, Bertozzini E, Penna A, Perini F, Pigalarga A, Graneli E, Magnani M (2008) Detection and quantification of Prymnesium parvum (Haptophyceae) by real-time PCR. Lett Appl Microbiol 46:261-266

Galluzzi L, Penna A (2010) Quantitative PCR for detection and enumeration of phytoplancton. In: Karlson B., Cusack C, Bresnan E (eds) Microscopic and molecular methods for quantitative phytoplankton analysis. Intergovernmental Oceanographic Commission of UNESCO IOC Manuals and Guides, no 55 Paris, pp 95-102

Galluzzi L, Bertozzini E, Penna A, Perini F, Garcés E, Magnani M (2010) Analysis of rRNA gene content in the Mediterranean dinoflagellate Alexandrium catenella and Alexandrium taylori: implications for the quantitative real-time PCR-based monitoring methods. J Appl Phycol 22:1-9

Garcés E, Bravo I, Vila M, Figueroa RI, Maso M, Sampedro N (2004) Relationship between vegetative cells and cyst production during Alexandrium minutum bloom in Arenys de Mar harbour (NW Mediterranean). J Plank Res 26:637-645

Garneau M, Schnetzer A, Countway PD, Jones AC, Seubert EL, Caron DA (2011) Examination of the seasonal dynamics of the toxic dinoflagellate Alexandrium catenella at Redondo Beach, California, by quantitative PCR. Appl Environ Microbiol 77:7669-7680

Glibert PM, Seitzinger S, Heil CA, Burkholder JM, Parrow MW, Codispoti LA, Kelly V (2005) The role of eutrophication in the global proliferation of harmful algal blooms: new perspectives and new approaches. Oceanogr 18:198-209

Godhe A, Cusack C, Pedersen J, Andersen P, Anderson DM, Bresnan E, Cembella A, Dahl E, Diercks S, Elbrachter M, Edler L, Galluzzi L, Gescher C, Gladstone M, Karlson B, Kulis D, LeGresley M, Lindahl O, Marin R, McDermott G, Medlin LK, Naustvoll L, Penna A, Tobe $\mathrm{K}$ (2007) Intercalibration of classical and molecular techniques for identification of Alexandrium fundyense (Dinophyceae) and estimation of cell densities. Harmful Algae 6:56-72

Godhe A, Asplund ME, Härnström K, Saravanan V, Tyagi A, Karunasagar I (2008) Quantification of diatom and dinoflagellate biomasses in coastal marine seawater samples by real-time PCR. Appl Environ Microbiol 74:7174-7182

Goel G, Kumar A, Puniya AK, Chen W, Singh K (2005) Molecular beacon: a multitask probe. J Appl Microbiol 99:435-442

Greenfield D, Marin R, Doucette G, Mikulski C, Jones K, Jensen S, Roman B, Alvarado N, Feldman J, Scholin C (2008) Field applications of the second-generation Environmental Sample Processor (ESP) for remote detection of harmful algae: 2006-2007. Limnol Oceanogr Meth 6:667-679

Hallegraeff GM (1992) Harmful algal blooms in the Australian region. Mar Pollut Bull 25:186-190

Hallegraeff GM (2010) Ocean climate change, phytoplankton community responses, and harmful algal blooms: a formidable predictive challenge. J Phycol 46:220-235

Handy SM, Hutchins DA, Cary SC, Coyne KJ (2006) Simultaneous enumeration of multiple raphidophyte species by quantitative real-time PCR: capabilities and limitations. Limnol Oceanogr Meth 4:193-204 
Hosoi-Tanabe S, Sako Y (2005) Species-specific detection and quantification of toxic marine dinoflagellates Alexandrium tamarense and A. catenella by real-time PCR assay. Mar Biotech 7:506-514

Howard MDA, Jones AC, Schnetzer A, Countway PD, Tomas CR, Kudela RM, Hayashi K, Chia P, Caron DA (2012) Quantitative real-time polymerase chain reaction for Cochlodinium fulvescens (Dinophyceae), a harmful dinoflagellate from California coastal waters. J Phycol 48:384-393

Jester RJK, Baugh A, Lefebvre KA (2009) Presence of Alexandrium catenella and paralytic shellfish toxins in finfish, shellfish and rock crabs in Monterey Bay, California USA. Mar Biol 156:493504

Kamikawa R, Nagai S, Itakura S, Sako Y (2005) Development of a quantification assay for the cysts of the toxic dinoflagellate Alexandrium tamarense using real-time polymerase chain reaction. Fish Sci 71:987-991

Kamikawa R, Asai J, Miyahara T, Murata K, Oyama K, Yoshimatsu S, Yoshida TSY (2006) Application of a real-time PCR assay to a comprehensive method of monitoring harmful algae. Microbes Environ 21:163-173

Kamikawa R, Nagai S, Hosoi-Tanabe S, Itakura S, Yamaguchi M, Uchida Y, Baba T, Sako Y (2007) Application of real-time PCR assay for detection and quantification of Alexandrium tamarense and Alexandrium catenella cysts from marine sediments. Harmful Algae 6:413-420

Kavanagh S, Brennan C, O'Connor L, Moran S, Salas R, Lyons J, Silke J, Maher M (2010) Real-time PCR detection of Dinophysis species in Irish coastal waters. Mar Biotech 12:534-542

Kellmann R, Mihali TK, Jeon YJ, Pickford R, Pomati F, Neilan B (2008) Biosynthetic intermediate analysis and functional homology reveal a saxitoxin gene cluster in cyanobacteria. Appl Environ Microbiol 74:4044-4053

Koskenniemi K, Lyra C, Rajaniemi-Wacklin P, Jokela J, Sivonen K (2007) Quantitative real-time PCR detection of toxic Nodularia cyanobacteria in the Baltic Sea. Appl Environ Microbiol 73:2173-2179

Kutyavin IV, Afonina IA, Mills A, Gorn VV, Lukhtanov EA, Belousov ES, Singer MJ, Walburger DK, Lokhov SG, Gall AA, Dempcy R, Reed MW, Meyer RB, Hedgpeth J (2000) 3'-minor groove binderDNA probes increase sequence specificity at PCR extension temperatures. Nucleic Acids Res 28:655-661

Lilly E, Halanych K, Anderson D (2007) Species boundaries and global biogeography of the Alexandrium tamarense complex (Dinophyceae). J Phycol 43:1329-1338

Lin S, Zhang H, Dubois A (2006) Low abundance distribution of Pfiesteria piscicida in Pacific and Western Atlantic as detected by $\mathrm{mtDNA}-18 \mathrm{~S}$ rDNA real-time polymerase chain reaction. J Plank Res 28:667-681

Livak KJ, Flood SJ, Marmaro J, Giusti W, Deetz K (1995) Oligonucleotides with fluorescent dyes at opposite ends provide a quenched probe system useful for detecting PCR product and nucleic acid hybridization. PCR Meth Appl 4:357-362

Manning SR, La Claire JW II (2010) Multiplex PCR methods for the species-specific detection and quantification of Prymnesium parvum (Haptophyta). J Appl Phycol 22:587-597

Marin III R, Scholin C. (2010) Sandwich hybridization. In: Karlson B., Cusack C, Bresnan E (eds) Microscopic and molecular methods for quantitative phytoplankton analysis. Intergovernmental Oceanographic Commission of UNESCO IOC Manuals and Guides, no 55 Paris, pp 87-94

Martins A, Vasconcelos V (2011) Use of qPCR for the study of hepatotoxic cyanobacteria population dynamics. Arch Microbiol 193:615-27

Mihali TK, Kellmann R, Muenchhoff J, Barrow KD, Neilan BA (2008) Characterization of the gene cluster responsible for cylindrospermopsin biosynthesis. Appl Environ Microbiol 74:716-722
Moffitt MC, Neilan BA (2004) Characterization of the nodularin synthetase gene cluster and proposed theory of the evolution of cyanobacterial hepatotoxins. Appl Environ Microbiol 70:63536362

Moore SK, Mantua NJ, Hickey BM, Trainer VL (2009) Recent trends in paralytic shellfish toxins in Puget Sound, relationships to climate, and capacity for prediction of toxic events. Harmful Algae 8:463-477

Moorthi S, Countway P, Stauffer B, Caron D (2006) Use of quantitative real-time PCR to investigate the dynamics of the red tide dinoflagellate Lingulodinium polyedrum. Microb Ecol 52:136-150

Murray SA, O'Connor WA, Alvin A, Mihali TK, Kalaitzis J, Neilan BA (2009) Differential accumulation of paralytic shellfish toxins from Alexandrium minutum in the pearl oyster, Pinctada imbricata. Toxicon 54:217-223

Murray SA, Wiese M, Stüken A, Brett S, Kellmann R, Hallegraeff G, Neilan BA (2011) STXA-based quantitative molecular assay to identify saxitoxin-producing harmful algal blooms in marine waters. Appl Environ Microbiol 77:7050-7057

Park TG, de Salas MF, Bolch CJS, Hallegraeff GM (2007) Development of a real-time pcr probe for quantification of the heterotrophic dinoflagellate Cryptoperidiniopsis brodyi (Dinophyceae) in environmental samples. Appl Environ Microbiol 73:2552-2560

Park TG, Park G-H, Park Y-T, Kang Y-S, Bae H-M, Kim C-H, Jeong H-J, Lee Y (2009) Identification of the dinoflagellate community during Cochlodinium polykrikoides (Dinophyceae) blooms using amplified rDNA melting curve analysis and real-time PCR probes. Harmful Algae 8:430-440

Penna A, Battocchi C, Garcés E, Anglés S, Cucchiari E, Totti C, Kremp A, Satta C, Giacobbe MG, Bravo I, Bastianini M (2010) Detection of microalgal resting cysts in European coastal sediments using a PCR-based assay. Deep Sea Re II 57:288-300

Perini F, Casabianca A, Battocchi C, Accoroni S, Totti C, Penna A (2011) New approach using the real-time PCR method for estimation of the toxic marine dinoflagellate Ostreopsis cf. ovata in marine environment. PLoS One 6:e17699

Popels LC, Cary SC, Hutchins DA, Forbes R, Pustizzi F, Gobler CJ, Coyne KJ (2003) The use of quantitative polymerase chain reaction for the detection and enumeration of the harmful alga Aureococcus anophagefferens in environmental samples along the United States East Coast. Limnol Oceanogr Meth 1:92-102

Reed GH, Kent JO, Wittwer CT (2007) High-resolution DNA melting analysis for simple and efficient molecular diagnostics. Pharmacogenomics 8:597-608

Rouhiainen L, Vakkilainen T, Siemer BL, William Buikema W, Haselkorn R, Sivonen K (2004) Genes coding for hepatotoxic heptapeptides (microcystins) in the cyanobacterium Anabaena Strain 90. Appl Environ Microbiol 70:686-692

Ryan J, Greenfield D, Marin R, Preston C, Roman B, Jensen S, Pargett D, Birch J, Mikulski C, Doucette G, Scholin C (2011) Harmful phytoplankton ecology studies using an autonomous molecular analytical and ocean observing network. Limnol Oceanogr 56:1255-1272

Sellner KG (1997) Physiology, ecology, and toxic properties of marine cyanobacteria blooms. Limnol Oceanogr 42:1089-1104

Scholin CA, Marin R, Doucette GJ, Powell CL, Haydock P, Howard J, Ray J (1999) DNA probes and a receptor-binding assay for detection of Pseudo-nitzschia (Bacillariophyceae) species and domoic acid activity in cultured and natural samples. J Phycol 35:1356-1367

Stüken A, Orr RJS, Kellmann R, Murray SA, Neilan BA, Jakobsen KS (2011) Discovery of nuclear-encoded genes for the neurotoxin saxitoxin in dinoflagellates. PLoS One 6:e20096

Tindall EA, Petersen DC, Woodbridge P, Schipany K, Hayes VM (2009) Assessing high-resolution melt curve analysis for accurate 
detection of gene variants in complex DNA fragments. Hum Mutat 30:876-83

Töbe K, Eller G, Medlin LK (2006) Automated detection and enumeration for toxic algae by solid-phase cytometry and the introduction of a new probe for Prymnesium parvum (Haptophyta: Prymnesiophyceae). J Plank Res 28:643-657

Töbe K, Kullis D, Gladstone M, Anderson D, Medlin LK (2010) Detecting intact algal cells with whole cell hybridisation assays, microscopic and molecular methods for quantitative phytoplankton analysis. In: Karlson B., Cusack C, Bresnan E (eds) Microscopic and molecular methods for quantitative phytoplankton analysis. Intergovernmental Oceanographic Commission of UNESCO IOC Manuals and Guides, no 55 Paris, pp 55-66

Touzet N, Keady E, Raine R, Maher M (2009) Evaluationof taxaspecific real-time PCR, whole-cell FISH and morpho taxonomy analyses for the detection and quantification of the toxic microalgae Alexandrium minutum (Dinophyceae), global clade ribotype. FEMS Microbiol Ecol 67:329-341

Trainer VL, Bates SS, Lundholm N, Thessen AE, Cochlan WP, Adams NG, Trick CG (2012) Pseudo-nitzschia physiological ecology, phylogeny, toxicity, monitoring and impacts on ecosystem health. Harmful Algae 14:271-300
Ulrich RM, Casper ET, Campbell L, Richardson B, Heil CA, Paul JH (2010) Detection and quantification of Karenia mikimotoi using real-time nucleic acid sequence-based amplification with internal control RNA (IC-NASBA). Harmful Algae 9:116-122

Vandersea MW, Kibler SR, Holland WC, Tester PA, Schultz TF, Faust MA, Holmes MJ, Chinain M, Litaker WR (2012) Development of semi-quantitative PCR assays for the detection and enumeration of Gambierdiscus species (Gonyaulacales, Dinophyceae). J Phycol 48:902-915

Wilson IG (1997) Inhibition and facilitation of nucleic acid amplification. Appl Environ Microbiol 63:3741-3751

Yeung PK, Kong KF, Wong FT, Wong JT (1996) Sequence data for two large-subunit rRNA genes from an Asian strain of Alexandrium catenella. Appl Environ Microbiol 62:4199-4201

Yuan J, Mi T, Zhen Y, Yu Z (2012) Development of a rapid detection and quantification method of Karenia mikimotoi by real-time quantitative PCR. Harmful Algae 17:83-91

Zamor RM, Glenn KL, Hambright KD (2012) Incorporating molecular tools into routine $\mathrm{HAB}$ monitoring programs: using qPCR to track invasive Prymnesium. Harmful Algae 15:1-7

Zhang H, Lin S (2005) Development of a cob-18S rRNA gene realtime PCR assay for quantifying Pfiesteria shumwayae in the natural environment. App Environ Microbiol 71:7053-7063 